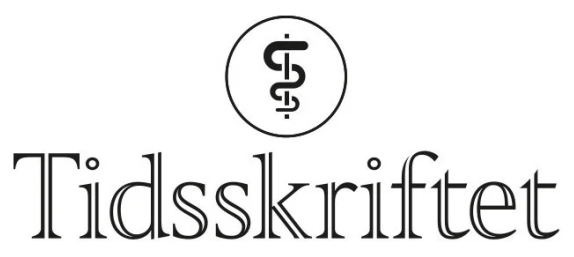

DEN NORSKE LEGEFORENING

\title{
Forskning som unndrar seg etterprøving
}

SPRÅKSPALTEN

ERLEND HEM

erlend.hem@medisin.uio.no

Erlend Hem er instituttsjef ved Legeforskningsinstituttet, professor ved Universitetet i Oslo og leder av Gruppe for norsk medisinsk fagspråk.

\section{Forskning som ikke blir publisert i vitenskapelige tidsskrifter, omtales på engelsk som stealth research. Hva skal vi kalle det på norsk?}

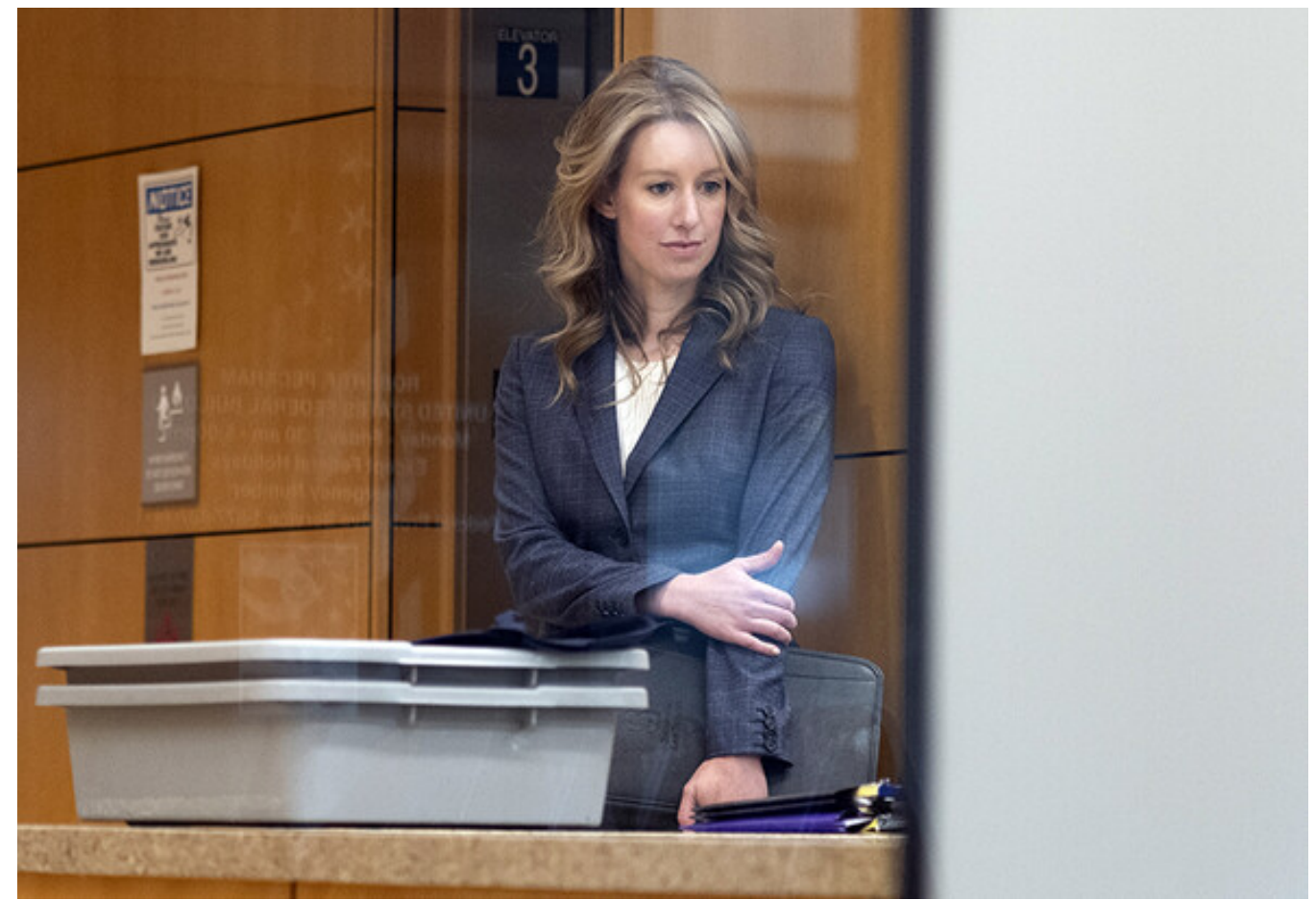

Elizabeth Holmes (f. 1984) ble omtalt som den neste Steve Jobs, men må nå møte i retten anklaget for «massiv svindel». Foto: Yichuan Cao / NTB

I 2003 startet Elizabeth Holmes, bare 19 år gammel, legemiddelselskapet Theranos - navnet var satt sammen av therapy og diagnosis (1). Firmaet tilbød en ny og revolusjonerende metode for å teste for en rekke sykdommer, ved hjelp av en dråpe blod og en maskin kalt 
Edison (므). Hun fikk med seg kjente navn i amerikansk politikk og samfunnsliv og ble USAs yngste selvgjorte kvinnelige milliardær. På det meste var Theranos verdsatt til ni milliarder dollar (3). Selskapet kvalifiserte dermed til betegnelsen enhjørning (engelsk: unicorn), det vil si en oppstartsbedrift verdsatt til over én milliard dollar (4).

Dessverre var det hele en bløff. Teknologien hadde aldri fungert, og Holmes møter høsten 2021 i retten siktet for «massiv svindel». Hun risikerer inntil 20 års fengsel dersom hun blir funnet skyldig (3). Hvordan kunne det skje? Fagfolk har påpekt at metoden og bruken av den aldri ble publisert i fagfellebaserte vitenskapelige tidsskrifter. Slik publisering ville trolig ha avdekket problemer og hindret at saken endte i en skandale (2).

Theranos er bare ett av mange eksempler på at angivelige medisinske gjennombrudd blir lansert utenfor vitenskapelige tidsskrifter $(4,5)$. Når forskningsresultater ikke blir presentert for et vitenskapelig publikum, forblir mye uklart. Det blir gjerne en miks av påstått briljante ideer, aggressiv markedsføring og opphaussing i massemediene (므,7.). Slik virksomhet er ikke ny. Militær forskning blir ofte utført på denne måten, og atombomben er et viktig eksempel.

Virkelig banebrytende nyskaping - innovasjon, som det ofte kalles - er sjelden. Kun en liten del av alle glupe ideer overlever grundig gransking (므). Så lenge denne typen forskning holder seg i skyggene, utenfor vitenskapelig kompetent vurdering, vil det ikke være mulig for investorer, leger, pasienter eller publikum å vurdere om innovasjonen er verdt ni milliarder, ni hundre millioner eller ni dollar $(\underline{6})$.

\section{Stealth på norsk}

Stealth research er definert som forskning som ikke er kommunisert i fagfellevurdert forskningslitteratur (1). Men hva betyr egentlig stealth i denne sammenhengen, og hva skal stealth research kalles på norsk?

I ordboka står det at stealth kan ha to betydninger ( $\underline{8})$ : det å liste eller snike seg og det å være usynlig. Hvis man gjør noe by stealth, så gjør man det i smug, i hemmelighet, i det stille. I militæret må man ofte det, og her finner vi eksempler som stealth airplane, et "usynlighetsfly» som er vanskelig å oppdage på radar (9.). Slike fly er et eksempel på stealth technology eller usynlighetsteknologi, der man bruker materialer og former som gjør objektet vanskelig å oppdage. Adjektivet stealthy handler om noe ubemerket eller hemmelig: She gave him a stealthy glance betyr at hun ga han et stjålent blikk (ㅁ).

Stealth research kunne oversettes med forskning $i$ smug, forskning $i$ hemmelighet eller usynlighetsforskning. Det beste er nok heller å beskrive kort hva slik forskning er, nemlig forskning som unndrar seg etterprøving.

\section{LITTERATUR}

1. Ioannidis JP. Stealth research and Theranos: reflections and update 1 year later. JAMA 2016; 316:3899o. [PubMed][CrossRef]

2. Schwettmann L, Eikeland J. Forenklet laboratoriediagnostikk. Tidsskr Nor Legeforen 2019; 139. doi: 10.4045/tidsskr.17.1097. [PubMed][CrossRef]

3. Kaspersen L. Hun sto bak et av tidenes mest skandaløse oppstartsselskaper - nå er rettssaken utsatt i fire måneder. Dagens Næringsliv 20.12.2020. https://www.dn.no/helse/helse/medisin/okonomiskkriminalitet/hun-sto-bak-et-av-tidenes-mest-skandalose-oppstartsselskaper-na-er-rettssaken-utsatt-ifire-maneder/2-1-934366 Lest: 20.12.2020.

4. Cristea IA, Cahan EM, Ioannidis JPA. Stealth research: Lack of peer-reviewed evidence from healthcare unicorns. Eur J Clin Invest 2019; 49. doi: 10.1111/eci.13072. [PubMed][CrossRef]

5. Hem E. Børsrakett forlenger livet? Tidsskr Nor Legeforen 2011; 131: 1985. [PubMed][CrossRef]

6. Ioannidis JP. Stealth research: is biomedical innovation happening outside the peer-reviewed literature? JAMA 2015; 313: 663-4. [PubMed][CrossRef] 
7. Carreyrou J. Bad blood: secrets and lies in a Silicon Valley startup. New York: Alfred A. Knopf, 2019.

8. Stor engelsk-norsk ordbok. https://www.ordnett.no/search?language=en\&phrase=stealth Lest: 20.12.2020.

9. Teknisk engelsk-norsk ordbok. https://www.ordnett.no/search? language=en\&phrase=stealth\%20airplane Lest: 20.12.2020.

Publisert: 11. oktober 2021. Tidsskr Nor Legeforen. DOI: 10.4045/tidsskr.21.0027

(C) Tidsskrift for Den norske legeforening 2023. Lastet ned fra tidsskriftet.no 26. april 2023. 